\title{
Effect of Lannat Pesticide on Growth Performance and Chromosomal Aberrations in Nile Tilapia (Oreochromis Niloticus L.)
}

\author{
Asmaa A. Khaled ${ }^{1}$
}

\begin{abstract}
Nile Tilapia, (Oreochromis niloticus L.,) is the most popular animal protein for Egyptian people due to their price and availability. Todays, agll the production fish exposed to biotic and abiotic environmental stress, that cause huge damage for the fish and costumers. During the current research one common pesticide "Lannat" was used by different concentrations i.e. $0.8,1.6$ and $3.2 \mathrm{ppm}$, to investigate the possible genotoxic effect in aquatic organisms, measurement and alteration by the physicochemical properties of DNA and isolated chromatin from liver tissue and finally, investigating the chromosomal aberrations in vivo induction of sister chromatid exchange (SCEs). This work was carried out at the faculty of Agriculture Saba Basha during the period 2016-2017. The results showed that Mitotic activity in the gills of the control group was higher than in kidneys. In treatments, cells of gills displayed lower mitotic activity compared with that of kidneys. Different mitotic aberrations were recorded with high doses of Lannat such as stickiness and ring chromosomes, deletion, fragments, and Robertsonian Centric Fusion (RCF). Lannat showed that it can induce macro-DNA damage. Lysis of nucleus was also observed.
\end{abstract}

Key words: Fish, Oreochromis niloticus, Lannat, Aberrations, chromosome

\section{INTRODUCTION}

The effect of environmental contaminations on human health is one of the most challenging problems that faces the world today. The growing world economy and the movement toward global market have driven competition in industrial and technological development at a high speed toward the betterment of mankind. However, in nearly all countries such development has focused on increased production and economic gains before realizing their impact on the environment, as well as human health. The continuously increasing population and the need to increase agricultural productivity have encouraged extensive use successive large-scale aerial and ground application of insecticides to control insect pests mainly on cotton, maize, and rice crops during the hot summer in Egypt are repeatedly associated with many poisoning to humans. It is well known that disposal of pollutant into aqueos ecosystems can lead to their accumulation both in sediments and the upper food chain (including fish). The study of water contamination by man's activities is important for man himself since the aquatic environment is a source of human exposure to xenobiotics. Because of low public and governmental interest in environmental mutagenesis and carcinogenic. It is believed that wild and cultured fish are already exposed to relatively high levels of this uncontrolled carcinogenic mutagenic chemicals as industrial waste products, which affect health. One mean of detecting in vivo genetic activity, of an environmental pollutant, is to examine mitotically active cells that have been arrested at metaphase for structural changes and rearrangement of their chromosomes. The occurrence of such aberrations correlates well with administration of known mutagen to animals and thus may serve as an indicator for possible mutagenic potential of test articles (Adler 1984 and Brusick 1984). The activity of chromatin can also be measured by its stablization degree against thermal denaturation. Temperature of melting, Tm-value is characterized by the transition range at which half of all hyperchromicity has manifested itself at which half of double stranded DNA are desaturated and become single stranded. (Seehy et al., 1995). Aquatic animals have often been used in bioassay to monitor water quality of effluent and surface waters (Bruges et al., 1977). Organophosphate (OP) pesticides are used worldwide to control arthropod pests in agriculture and aquaculture, and often end up polluting waterways (Coelho et al., 2011, Jordaan et al., 2013; Tierney et al., 2007; Var? et al., 2008). The development of biological monitoring techniques based on fish offers the possibility of checking water pollution with fast responses on low concentrations of direct-acting toxicants (Seehy et al., 2009). However, mutagenic or carcinogenic compounds and compounds that require bioactivation into reactive metabolites may pass unnoticed in hazardous quantities. Fish provide an excellent source of material for the study of mutagenic and/or carcinogenic potential of water samples since they are aquatic vertebrate organisms that can metabolize, concentrate and store water-borne pollutants (Al-sabti, 1991). The present work aims at investing the capacity of one selected environmental contaminants, namely Lannat (Pesticide) to induce genetic damage in aquatic organisms. To achieve such a purpose Oreochromis niloticus fish were chosen and employed. However, the study was carried out at two levels: (a) Molecular level: by measurement

\footnotetext{
${ }^{1}$ Animal and Fish Production Department, Faculty of Agriculture Saba Basha, Alexandria University (Dr.asmaa_khaled@alexu.edu.eg) Received November 03,2017, Accepted November26, 2017
} 
of alteration in the physico-chemical properties of DNA and chromatin isolated from liver tissue. (b) Cytogenetic level: by investigating the structural and/or numerical chromosomal aberrations and in vivo induction of sister chromatid exchange (SCEs).

\section{MATERIALS AND METHODS}

Experimental fish individuals were obtained from private fish farm near Edku Lake, El-Behaira government, Egypt. Fish were collected and transported to the laboratory in plastic bags filled with $30 \mathrm{~L}$ of water and they were kept for two weeks as an acclimatization period in circular fiber glass tanks; each of a capacity of one cubic meter in volume filled with 730 -liter water. Fish individuals, with an average body weight of $13.02 \pm 0.35 \mathrm{~g} / \mathrm{fish}$, were fed on a diet contained $32.38 \%$ crude protein, and treated for 6 weeks to Lannat (carbamate group) to investigate the chromosomes for any aberration, sister chromatid exchanges, alteration of physicochemical properties of DNA and chromatin. All ingredients of experimental diet were brought from the local market. Diet was completed with vitamins and minerals mixture according to NRC (1993). Oil was added drop by drop during mixing. Experimental fish fed two times a day (9.00-14.00 hrs) as shown in Table (1).

Table 1. Feed ingredients $(\%)$ of the experimental diet

$\begin{array}{lc}\text { Ingredient } & \% \\ \text { Fish Meal } & 24 \\ \text { Soybean } & 33 \\ \text { Yellow Corn } & 2 \vee \\ \text { Rice } & 06 \\ \text { Wheat Bran } & 06 \\ \text { Corn Oil } & 02 \\ \text { ins \& minerals mixture* } & 02\end{array}$

Vitamins \& minerals mixture*

02

* Vitamin \& minerals mixture (P-Fizzer, Cairo, Egypt)Contains $(/ \mathrm{kg})$ Vitamin A, 4.8 MIU ;Vitamin D, 0.8 MIU ;Vitamin E, 4.0 g; Vitamin $\mathrm{K}, 0.8 \mathrm{~g}$;Vitamin B1, 0.4 g; Vitamin B2 $1.6 \mathrm{~g}$; Vitamin B6 $0.6 \mathrm{~g}$; Vitamin B7, $20.0 \mathrm{mg}$; Vitamin B12 , $40.0 \mathrm{~g}$; Folic acid, $0.4 \mathrm{~g}$; Nicotinic acid, 8.0 g; Pantothenic acid , 4.0 g; Colin chloride, $200 \mathrm{G}$; Zinc, $22 \mathrm{~g}$; Copper , $4.0 \mathrm{~g}$; Iodine , $0.4 \mathrm{~g}$; Iron , $12.0 \mathrm{~g}$;Manganese, $22.0 \mathrm{~g}$; Selenium, $0.04 \mathrm{~g}$.

\section{Evaluation methods}

\section{1-Growth performance}

Control and treated fish were weighted at the beginning of the treatment and after 6 weeks of treatment. Body weight gain (BWG), average daily gain (ADG) and specific growth rate (SGR) were calculated according to the following equations (Ricker, 1975; Castell and Tiewes, 1980). Statistical analysis was performed using the F-test analysis. The flowing parameters were calculated i.e. total weight gain (g/fish) $=\mathrm{W}_{\mathrm{t}}-\mathrm{W}_{0}$, where: $\mathrm{W}_{0}$ : initial mean weight of fish in grams and $\mathrm{W}_{\mathrm{t}}$ : final mean weight of fish in grams; average daily gain $(\mathrm{ADG})(\mathrm{mg} / \mathrm{fish} /$ day $): \mathrm{ADG}=(\mathrm{Wt}-$ W0)/n, Where: n: duration period; specific growth rate $(\mathrm{SGR})(\% /$ day $): \mathrm{SGR}=100 \times\left(\ln \mathrm{W}_{\mathrm{t}}-\ln \mathrm{W}_{0}\right) /$ no.of days, Where: ln: natural logarithm.

\section{2-Analysis of chromosomal abnormalities in gills and kidneys}

Each animal had received $0.25 \mathrm{mg}$ colchicine per gram Fish. After two hrs., the fish was killed and gill and kidneys were removed. Preparation of chromosome complement was carried out according to the method that described by Seehy and Barakat (1995). Each organ was cut up with forceps several times and transferred to a morter containing $20 \mathrm{ml}$ of hypotonic solution $(0.075$ $\mathrm{KCL}$ ) and was gently homogenized, left for $15 \mathrm{~min}$ at $37^{\circ} \mathrm{C}$. The homogenate was then filtered through one layer of nylon mesh. The filtrate was centrifuged for 10 min at $1200 \mathrm{rpm}$. The supernated was discarded and the pellet was centrifuged for $10 \mathrm{~min}$ at $1200 \mathrm{rpm}$. The supernated was discarded and the pellet was then suspended in methanol and acetic acid (3:1). The fixative was changed after 2 hours by centrifugation. Cell suspension was left overnight at $4^{\circ} \mathrm{C}$. Cells in fixative were dropped onto very clean glass slides and air dried. Spreads were stained with10/Gimsa at pH 6.8 for $5 \mathrm{~min}$. Scanning slides for mitotic spreads was conveniently accomplished with a25X magnification objective, and analysis was with a $100 \mathrm{X}$ objective. For control of bias, all prepared slides were coded prior to scoring.

\section{a-In vivo induction of sister chromatid exchange}

Bromodeoxyuridine treatment: Fish were injected once with $0.4 \mathrm{mg}$ BrdU per gram fish were exposed to this base analogue for 7 days. Seven hrs prior to killing, each specimen was injected with $0.25 \mathrm{mg}$ colchicine per gram fish. The fish were decapitated. The gills, kidneys and testicular tissues were removed and placed in 0.4 /hypotonic solution of KCL for $30 \mathrm{~min}$. The organ was minced, homogenized with a Pasteur pipette in a tube filled with a cool $\left(4^{\circ} \mathrm{C}\right)$ hypotonic solution $(0.4$ $\mathrm{KCl})$. Hypotonic treatment will continue at room temperature for $30 \mathrm{~min}$. One $\mathrm{ml}$ of fresh cool fixative (3 methanol: 1 glacial acetic acid) was add onto the hypotonic solution. The suspension was centrifuge at $1000 \mathrm{rpm}$ for $10 \mathrm{~min}$, the pellet was then gently resuspended in fresh fixative centrifuged. This step was repeated twice

\section{b-Preparation of metaphases}

The cells were dropped onto clean slides and air dried. Stained using the modified FPG (Fluorescence plus Gimsa) technique. Preparation were first treated with $50 \mu \mathrm{g}$ Hoechs 33258 (per $\mathrm{ml} \mathrm{H}_{2} \mathrm{O}$ ) for $15 \mathrm{~min}$ in the dark, rinsed in distilled water and then exposed to ultraviolet radiation for $4 \mathrm{~h}$ in Mcillvan buffer $\mathrm{PH} 7$. 
Preparation were then heated for $40 \mathrm{~min}$ at $60 \mathrm{C}$ and stained in 10/Giemsa to PH6.8 for $10 \mathrm{~min}$. Scanning slides for mitotic spreads was conveniently accomplished with a25X magnification objective, and analysis was a $100 \mathrm{X}$ objective. For control exchange frequencies were counted from the microscope images of second division cells. An interstitial exchanged segment was counted to be 2 SCE's.

\section{c-Physico-chemival properties of chromatin}

To isolation chromatin, the frozen livers were transferred into a chilled mortar and ground well, bit by bit, using small amounts of the following buffer:0.075 M NACL, 0.01 M Na -citrate, 0.01 MTris-HCL, pH8.0 (Fellenberg, 1974 and Seehy et al., 1990). Then the ground tissues were homogenized in the same buffer (about $3 \mathrm{ml}$ for each gram liver) with a high-speed blender for 3 minutes. The homogenized was filtered through three layers of nylon mesh (had pore size of about $30 \mu$ ). The filtrate was centrifuged for $30 \mathrm{~min}$ at $7000 \mathrm{Xg}$ at $0 \mathrm{C}$. The pellet was suspended in the same buffer and centrifuged at $15000 \mathrm{Xg}$ for $10 \mathrm{~min}$. This step was repeated four times. Then, the pellet was suspended in the following buffer: $0.03 \mathrm{M} \mathrm{NaCl}$ and 0.01 MTris$\mathrm{HCl}, \mathrm{pH} 8.0$ and centrifuged at $15000 \mathrm{Xg}$ for $10 \mathrm{~min}$ at 0C. For chromatin extraction, the recovered pellet was gently stirred for one hour in $1 \mathrm{M} \mathrm{NaCl}, 0.01 \mathrm{M}$ Tris$\mathrm{HCl}, \mathrm{pH} 7.2$ and kept overnight at $2 \mathrm{C}$. The chilled mixture was then centrifuged at $25000 \mathrm{Xg}$ for $30 \mathrm{~min}$, and the supernatant containing the chromatin was kept in a sterilized vial a refrigerator.

\section{d-Purification of chromatin}

Chromatin was purified by filtration through sephadex G-25 Fine, using the $1 \mathrm{M} \mathrm{NaCl}$ buffer. The purity of chromatin preparation was checked using the following criteria: (1) Absorbance at 260nm/ absorbance at $280 \mathrm{~nm}=1.5$; (2) Absorbance at $280 \mathrm{~nm} /$ absorbance at $260 \mathrm{~nm}=0.5-0.6$ and (3) Absorbance at $320 \mathrm{~nm} /$ absorbance at $260 \mathrm{~nm} \geq 0.1$ thermal stability and chemical composition of chromatin: chromatin was dialyzed three times at $2^{\circ} \mathrm{C}$ against the following buffer:0.0014 M NaCl, 0.00025 M Tris-Hcl, PH 7.2. The UV absorbance for the chromatin at both 260 and $280 \mathrm{~nm}$ was recorded at every one-degree increase in temperature (heating rate was $1 \mathrm{C} / \mathrm{min}$ ). Relative

Table 2. Effects of Lannat on final body weight (FBW), body weight gain (BWG), average daily gain (ADG), specific growth rate (SGR) and survival (\%) of O.niloticus after 6 weeks treatment

\begin{tabular}{cccccccc}
\multicolumn{2}{c}{$\begin{array}{c}\text { Concentration } \\
(\mathbf{p p m})\end{array}$} & $\begin{array}{c}\text { Initial body } \\
\text { weight }\end{array}$ & $\begin{array}{c}\text { FBW } \\
(\mathbf{g} / \text { fish) }\end{array}$ & $\begin{array}{c}\text { BWG } \\
(\mathbf{g} / \text { fish })\end{array}$ & $\begin{array}{c}\text { ADG } \\
(\mathbf{g} / \text { fish/day) }\end{array}$ & $\begin{array}{c}\text { SGR } \\
(\% / \text { day })\end{array}$ & $\begin{array}{c}\text { Survival } \\
(\%)\end{array}$ \\
Control & $(0.0)$ & $12.99 \pm 0.29$ & $21.51 \pm 0.19^{\mathbf{a}}$ & $8.52 \pm 0.22^{\mathbf{a}}$ & $0.152 \pm 0.12^{\mathbf{a}}$ & $0.901 \pm 0.01^{\mathbf{a}}$ & $100.00 \pm 0.00$ \\
& 0.8 & $13.08 \pm 0.21$ & $19.00 \pm 0.15^{\mathbf{b}}$ & $5.95 \pm 0.39^{\mathbf{b}}$ & $0.106 \pm 0.17^{\mathbf{b}}$ & $0.667 \pm 0.03^{\mathbf{b}}$ & $89.52 \pm 5.13$ \\
Lannat & 1.6 & $13.05 \pm 0.19$ & $17.75 \pm 0.26^{\mathbf{c}}$ & $4.70 \pm 0.35^{\mathbf{c}}$ & $0.084 \pm 0.25^{\mathbf{b c}}$ & $0.549 \pm 0.05^{\mathbf{b c}}$ & $85.95 \pm 7.45$ \\
& 3.2 & $12.95 \pm 0.31$ & $17.05 \pm 0.11^{\mathbf{c}}$ & $4.10 \pm 0.41^{\mathbf{c}}$ & $0.073 \pm 022^{\mathbf{c}}$ & $0.491 \pm 0.06^{\mathbf{c}}$ & $81.05 \pm 9.13$ \\
\hline
\end{tabular}

*Means followed with the same letter(s) are not significantly different. absorbance was calculated as relative to the absorbance at 50C (Spang and Platt, 1972). Computerized Image Analysis in Scientific Applications System, Lica company was used at department genetic Faculty of agriculture Cairo university, Giza Egtpt to estimate and analyze the grey values (G-values) of the cells. Briefly, this microphotometric scanning analysis is composed of computer and a transmission microscope coupled with low resolution by a linear phototidic array, and the addresses of the objects, tagged as cells were stored in the memory. Individual cells were recalled system's memory were relocated for high resolution analysis and evaluated. To obtain the most accurate image representation, CIASA interface a microscope image to an apparatus that digitizes the image by combining a process of scanning and photodetection. The cells population were characterized by the histogram of cell distribution according to their nuclear DNA content as expressed by integrated optical density (IOD).

\section{a-Growth performance}

Results presented in Table (2) summarized the effects of Lannat pesticide on growth performance and survival rate $(\%)$ of $O$. niloticus. The results showed that treated fish after six weeks of exposure with Lannat indicated high significantly values $(\mathrm{p}<0.05)$ lower final body weight (FBW, g/fish), weight gain (WG, g/fish), average daily gain (ADG, g/fish/day) and specific growth rate (SGR, \%/day) compared to untreated fish (Table 2).

\section{b-Mitotic activity}

Mitotic activity in gills and kidneys of fish of control group was examined. Mitotic activity in the gills of the control group was shown to be higher than that in kidneys. In treatments, cells of gills displayed lower mitotic activity compared with that of kidneys. Such a result, however, is expected, since gills resent the first target for treatment. Normal mitotic activity is shown in Figure 1 (a) and data in Figure 1 (b). showing nucleus in lysis after treatment with $3.2 \mathrm{ppm}$ Lannat in Oreochromis niloticus. an electrooptical system. cell images were digested at 
Table 3.Chromosomal abnormalities percent in gills of Oreochromis niloticus after treatment with Lannat

\begin{tabular}{cccccc}
\hline \multicolumn{2}{c}{ Concentration (ppm) } & Deletion & Stickiness & Fragment & $\begin{array}{c}\text { Total aberrant } \\
\text { Metaphases }\end{array}$ \\
Control & 0.0 & 1 & 1 & 0.5 & 2.5 \\
\multirow{4}{*}{ Lannat } & 0.8 & 2 & 7 & 3.5 & 10.5 \\
& 1.6 & 3 & 13 & 4.5 & 19.5 \\
& 3.2 & 5 & 16 & 5.5 & 20.5 \\
\hline
\end{tabular}

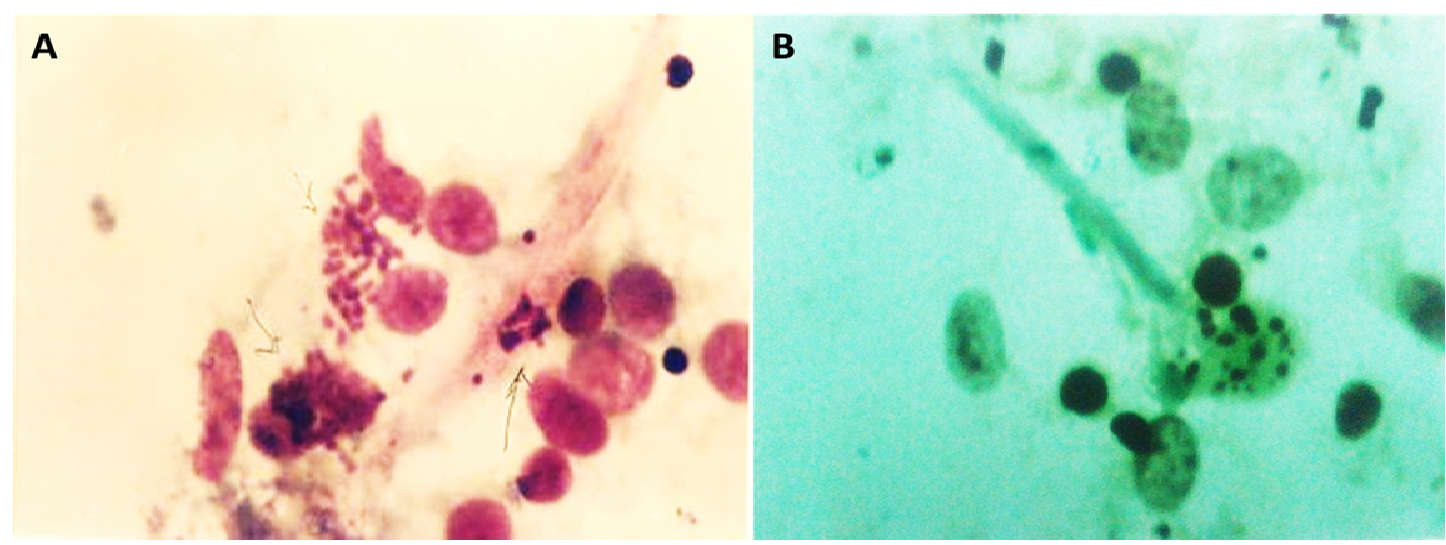

Figure 1. a. Normal mitotic activity and- b. showing nucleus in lysis after treatment with 3.2 ppm Lannat in Oreochromis niloticus



Figure 2. Showing metaphase stages in Oreochromis niloticus kidneys showing stickiness after Lannat treatment, $0.8,1.6$ and 3.2 , in respect

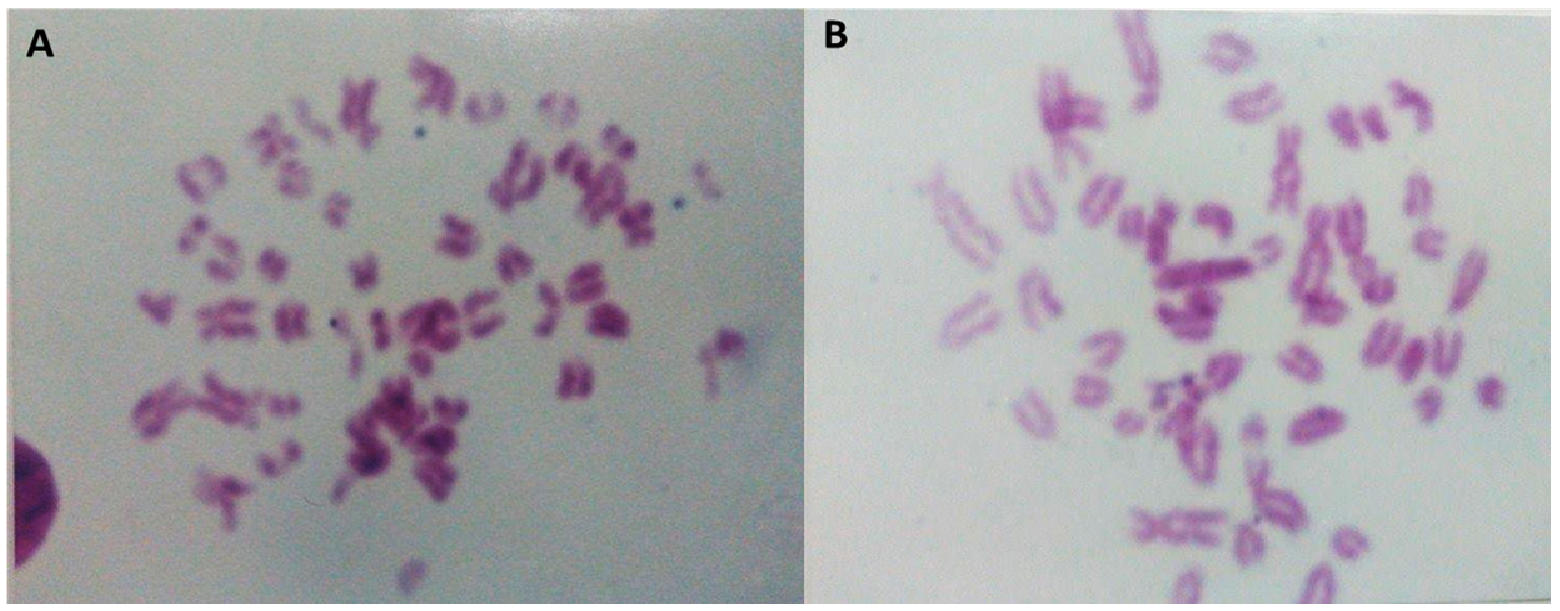

Figure 3. (a) Metaphase stages with stickiness and ring chromosomes, (b) showing RCF in metaphase stage of Oreochromis niloticus after 3.2 ppm Lannat treatment. 
Figure 2 showing metaphase stages in Oreochromis niloticus kidneys with stickiness after Lannat treatment. Figure 3 (a) showing metaphase stages with stickiness and ring chromosomes, (b) showing RCF in metaphase stage of Oreochromis niloticus after Lannat treatment. Examination of chromosome abnormalities after treatment with the Lannat showed that this can induce macro-DNA damage. Lysis of nucleus was observed (Figure 3). Different types of aberrations e.g. (deletion, fragments, stickiness and Robertsonian Centric Fusion (RCF) were obtained. (Table 3). Total aberrant metaphase in the control was found to be $2.5 \%$. It ranged from $10.5(0.8 \mathrm{ppm})$ to 20.5 (3.2 ppm) in gills of fish treated with Lannat. Although the insecticide was found to be effective in inducing stickiness, the range were from 7 to 16 with the high concentration, it was also proven to induce fragmentation.

\section{c-Sister chromatid exchanges:}

Analysis of sister chromatid exchange frequencies in gills of T.nilotica is given in Table 4 which illustrates the average of SCEs in treatment with Lannat compared with the control group. Sister chromosome exchanges ranged from $2.60 \pm 0.25$ in the control to $8.13 \pm 0.90$ after treatment with largest dose of Lannat (3.2 ppm). The tested concentration of Lannat was found to be positive in inducing significant increases of SCEs and a concentration response relationship was achieved (Table 4).

\section{d-Cytophotomtric Image Analysis:}

Image analysis revealed that the effect of insecticide Lannat upon the mitotic activity. Such effect was found to be increased with the increasing concentration of Lannat, and accordingly most of the examined cells remained in $G_{0}$ and $G_{1}$ (stages proceeding DNA replication). Such an effect leads to a significant decrease in the number of cells at S-phase. Table (5) and Figure (4). Regarding the effect of the treated insecticide Lannat, upon $T$. nilotica, the image analysis showed that it's effect was high. Such a result came from the observation that the treatment with Lannat increased the number of cells contained DNA less than 2n (Figure 4) as well as those contained more than $4 n$ (Figure 4). It was observed that at the lowest concentration of Lannat, there were 9 cells having DNA content less than 2 and 9 cells having DNA content more than $4 \mathrm{c}$, while at middle concentration of Lannat, 8 cells have DNA content less than 2 c, 13 cells have DNA content more than $4 \mathrm{c}$. At the highest concentration of Lannat 13 cells have DNA content less that $2 \mathrm{c}$ and 10 cells have DNA content more than 4c. Such effect however was found to be higher with the highest tested concentration of Lannat.

\section{e-Physico-chemical properties of chromatin:}

This part of the present study aims at investing the capability of Lannat in inducing an alteration in some of the Physico-chemical properties of chromatin isolated from fish liver. Seehy (1990) reported that $\pm 0.05{ }^{\circ} \mathrm{C}$ considering to be significant difference. Temperature of melting; melting profiles; and total hyperchromocity were calculated and the results obtained are given in Tables 6 and 7. Table (6) illustrate the relative absorbance estimated at $260 \mathrm{~nm}$ and $280 \mathrm{~nm}$ at temperature that ranged from 50 to $90^{\circ} \mathrm{C}$ for chromatin isolated from liver of the control group and that isolated after treatment either with the tested compound. Data showed the melting profiles of chromatin isolated after treatment with the selected concentration of Lannat compared with that of the control group. Such a comparison was carried out at 260 and $280 \mathrm{~nm}$ as well. Estimation of hyperchromicity was done at 260 and 280 $\mathrm{nm}$ as well. Table 5 shows the hyperchromicity estimated for liver chromatin isolated from Oreochromis niloticus after treatment with the selected concentration. At 260nm, Hyperchromicity ranged from 41.2 to $54 \%$. it ranged from 34.2 to $42.2 \%$. It is clear from this result that hyperchromicity was highly altered.

Table 4.Average of sister chromatid exchange in T.nilotica chromosomes after treatment with Lannat

\begin{tabular}{lcc}
\hline Concentrations & $\mathbf{X} \pm \mathbf{S E}$ & Range \\
Control & $2.60 \pm 0.25$ & $2: 4$ \\
$0.8 \mathrm{ppm}$ & $2.90 \pm 0.60$ & $2: 8$ \\
$1.6 \mathrm{ppm}$ & $6.25 \pm 0.40$ & $2: 12$ \\
$3.2 \mathrm{ppm}$ & $8.13 \pm 0.90$ & $4: 12$ \\
\hline
\end{tabular}

Table 5. Comparative DNA content in cells treated with different doses of Lannat and control

\begin{tabular}{lccc} 
Concentration & $\mathbf{2 C}$ & $\mathbf{S}$ & $\mathbf{4 C}$ \\
Control & 40 & 25 & 11 \\
$0.8 \mathrm{ppm}$ & 33 & 42 & 9 \\
$1.6 \mathrm{ppm}$ & 37 & 19 & 10 \\
$3.2 \mathrm{ppm}$ & 45 & 37 & 3 \\
\hline
\end{tabular}



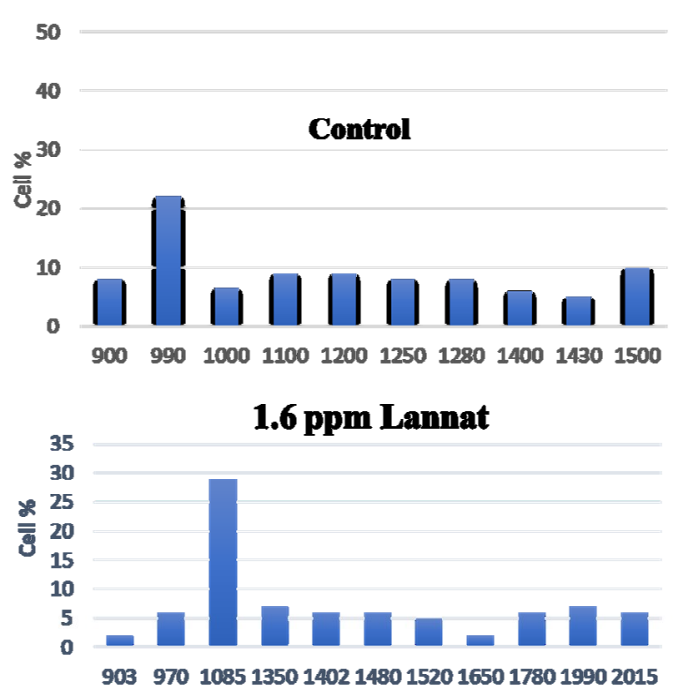
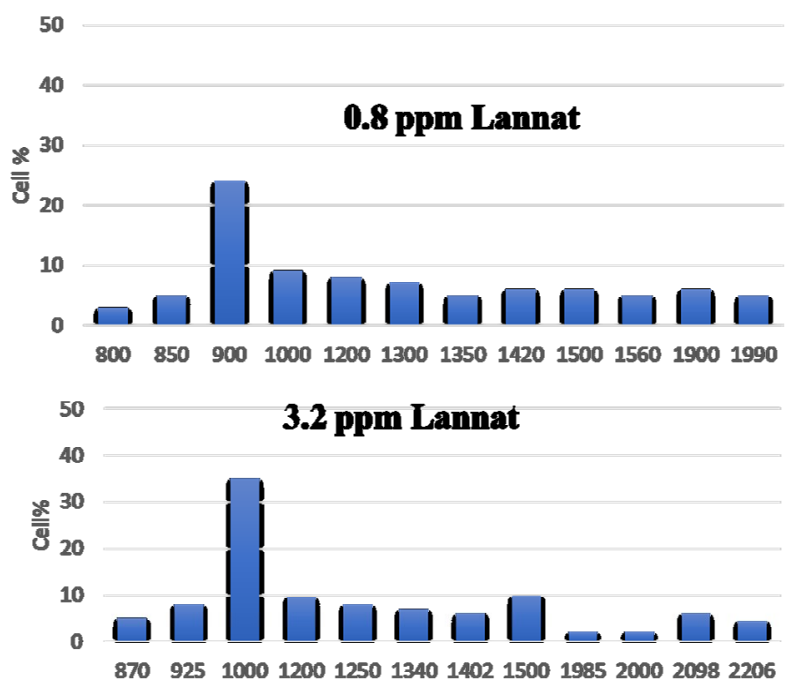

Figure 4. Relative DNA content in A.U. in fish used as control, treated with 0.8, 1.6 qnd 3.2 ppm Lannat

Temperature of melting was estimated at $260 \mathrm{~nm}$ and $280 \mathrm{~nm}$ as well at $260 \mathrm{~nm}$, liver chromatin of the control group displayed Tm-value of $73.5^{\circ} \mathrm{C}$. Tables 7 and 8 illustrates the values of Tm observed at $260 \mathrm{~nm}$ and $280 \mathrm{~nm}$ for chromatin isolated from fish liver after treatment with the tested concentration of the insecticide Lannat. At $260 \mathrm{~nm}$, Tm-values was $69^{\circ} \mathrm{C}$ after treatment of fish with 0.8 and $1.6 \mathrm{ppm}$ of Lannat. It was $70{ }^{\circ} \mathrm{C}$ after treatment with the highest tested concentration $3.2 \mathrm{ppm}$. Comparing these values with that obtained for the control group, one can conclude that temperature of melting decreased by about $4^{\circ} \mathrm{C}$. Such a decrease in Tm-value was found at $280 \mathrm{~nm}$, and reached $5^{\circ} \mathrm{C}$ (control compared with $1.6 \mathrm{ppm}$.

The current awareness of the potential hazards of pollutants in the aquatic environment has stimulated much interest in the use of fish as indicators for monitoring environmental carcinogens; dermatogens; mutagens; and clastogens. This is because aquatic environment serves as convenient repositories for man's biological and technological waters. Aquatic organisms in cytogenetic investing have the following properties: The karyotype should be suitable for observing chromosome aberrations; the mitotic activity should be sufficient to acure statistical number of metaphases; the test animals should be easily available by catching, buying, and culturing in environment, Thereby Tilapia provides an adequate organism for cytogenetic studies.

The present study was planned to investigate the effect of the insecticide Lannat upon Oreochromis niloticus genome. To achieve such a purpose, a variety of short term genotoxic bioassays were selected and employed to ass's micro and macro DNA damage.
These bioassays are: Analysis of chromosome behavior; In Vivo induction of Sister Chromatide Exchange; Measuring of DNA content and investing of some physico-chemical properties of chromatin isolated from liver., three selected concentrations represent 1/5, 1/10 and $1 / 20$ of $\mathrm{LC}_{50}$ of the chemical compound were used. However, the usefulness of Oreochromis niloticus_as higher eukaryotic test organism's foe environmental contaminants, is being more commonly recognized (Seehy et al., 1995). The different short-term bioassays which were employed in the present work assess the following types of lesions: InVivo chromosomal alterations which involve changes in number and/or structure of entire chromosomes and may include polyploidy, breakage, nondisjunction, and other forms of structural changes in somatic as well as germinal cells. An advantage of this assay, is that it takes account of the metabolism of the organism in vivo, cellular toxicity which measures the response of diving cells to the assayed chemical compound, and accordingly the activity of the compound upon the mitotic phases and cell cycle duration can be estimated and altration of gene expression at transcription and/or translation levels. With respect to mitotic activity, the results showed that mitotic activity in kidneys was higher than gills. Such a result is expected, science gills represent the first target for the aquatic contaminants. The analysis of chromosome behavior showed that Lannat can interact with Tilapia _ genome, since it was shown to be a positive inducer of nucleus fragmentation and fragment as well, tenfold increase in fragment compared with the control group were observed. Such a result, however, represents the first evidence that Lannat is a positive clastogen upon Tilapia_genome. Centric fusion 
was increased depending on the concentration used. The induction of Robertsonian Centric Fusions (RCF). Concerning methods for detection of primary DNA. the only practical in vivo_method is the sister chromatide exchange assay (Nakanishi and Schnider., 1979). The most extensive use of SCEs analysis was to assess the impact of clastogens on the chromosome (Allen et al., 1977). By using SCEs technique, Glysat showed a significant increase in the rate of SCE which increased with higher doses and a concentration-response relationship was achived while $\mathrm{HgCl}_{2}$ was found to be negative inducer of SCE. Such a result, however, represented an evidence that Lannat is a positive mutagen. The present work aims at disclosing the capabilty of one environmental pollutants in inducing micro- and macro-DNA damage in aquatic organism. This pollutant is: the insecticide Lannat. To achieve such a purpose. Oreochromis niloticus was chosen as a test material for the study. Mitotic activity: analysis of chromosome complements and chromosome aberrations as well; Sister chromatid exchanges; DNA content and physico-chemical properties of liver chromatin. The results obtained from this study can be summarized as follows. In the control group, mitotic activity in gills was found to be lower than that kidneys. After treatment, the result reveled that gills displayed lower mitotic activity than that of kidneys. Lannat was found to be powerful in causing significant decrease in mitotic activity compared with the tested insecticide Lannat. The results showed that Lannat was found to be a positive inducer of macro-DNA damage, since different types of aberrations were observed i.e. fragments; deletion; Robertsonian Centric Fusion and stikiness were observed. The results obtained indicated that the tasted Lannat was positive in causing primary DNA damage. The result obtained confirmed the conclusion that target for Lannat (and/or it's metabolites). Investigating temperature of melting, melting profiles and hyperchromicity, the results obtained showed that Lannat decreased the Tm values when compared with the control. The hyperchromicity wasn't highly altered by the insecticide Lannat. In conclusion, the results obtained from this study showed that Lannat is a positive inducer of genetic damage. This work, also recommends the use of Oreochromis niloticus chromosome to assess the effect of pollution upon aquatic environment.

Table 6. Relative absorbance (RA) at 260 and $280 \mathrm{~nm}$ of liver of chromatin isolated from Tilapia niltica (control group). Melting was carried out in diluted saline solution (0.0014 M Nacl) *RA: absorbance Relative was calculated according to spang and Platt (1972)

\begin{tabular}{|c|c|c|c|c|c|c|}
\hline \multirow{2}{*}{$\mathbf{T}^{\circ} \mathrm{C}$} & \multicolumn{3}{|c|}{$260 \mathrm{~nm}$} & \multicolumn{3}{|c|}{$280 \mathrm{~nm}$} \\
\hline & RA & $\mathrm{T}^{\circ} \mathrm{C}$ & RA & RA & $\mathbf{T}^{\circ} \mathrm{C}$ & RA \\
\hline 50 & 1.000 & 71 & 1.180 & 1.000 & 71 & 1.180 \\
\hline 51 & 1.000 & 72 & 1.200 & 1.000 & 72 & 1.096 \\
\hline 52 & 1.000 & 73 & 1.210 & 1.000 & 73 & 1.120 \\
\hline 53 & 1.000 & 74 & 1.260 & 1.000 & 74 & 1.124 \\
\hline 54 & 1.000 & 75 & 1.290 & 1.000 & 75 & 1.160 \\
\hline 55 & 1.000 & 76 & 1.296 & 1.000 & 76 & 1.190 \\
\hline 56 & 1.006 & 78 & 1.300 & 1.000 & 78 & 1.200 \\
\hline 57 & 1.008 & 79 & 1.310 & 1.000 & 79 & 1.220 \\
\hline 58 & 1.010 & 80 & 1.316 & 1000 & 80 & 1.240 \\
\hline 59 & 1.040 & 81 & 1.340 & 1.000 & 81 & 1.260 \\
\hline 60 & 1.050 & 82 & 1.380 & 1.000 & 82 & 1.280 \\
\hline 61 & 1.056 & 83 & 1.386 & 1.010 & 83 & 1.300 \\
\hline 62 & 1.060 & 84 & 1.392 & 1.012 & 84 & 1.310 \\
\hline 63 & 1.062 & 85 & 1.400 & 1.016 & 85 & 1.320 \\
\hline 64 & 1.070 & 86 & 1.420 & 1.018 & 86 & 1.330 \\
\hline 65 & 1.072 & 87 & 1.436 & 1.020 & 87 & 1.340 \\
\hline 66 & 1.074 & 89 & 1.436 & 1.024 & 89 & 1.342 \\
\hline 67 & 1.080 & 90 & 1.436 & 1.040 & 90 & 1.342 \\
\hline 68 & 1.100 & - & 1.436 & 1.046 & - & 1.342 \\
\hline 69 & 1.120 & - & 1.436 & 1.060 & -- & 1.342 \\
\hline 70 & 1.160 & - & - & 1.070 & - & - \\
\hline 71 & - & - & - & 1.160 & - & - \\
\hline
\end{tabular}


Table 7. Temperature of melting, Tm-value of chromatin and Hyperchromicity \% of Oreochromis niloticus liver after treatment with Lannat

\begin{tabular}{|c|c|c|c|c|c|}
\hline \multirow{2}{*}{ Concentration } & \multirow{2}{*}{ Tm-value } & \multirow{2}{*}{ Tm-280 } & \multirow{2}{*}{$\Delta \operatorname{Tm}(280-260)$} & \multicolumn{2}{|c|}{ Hyperchromicity \% } \\
\hline & & & & $260 \mathrm{~nm}$ & $280 \mathrm{~nm}$ \\
\hline Control & 73.5 & 75.5 & 2.0 & 43.6 & 34.2 \\
\hline $0.8 \mathrm{ppm}$ & 69.0 & 71.0 & 2.0 & 40.0 & 32.0 \\
\hline $1.6 \mathrm{ppm}$ & 69.0 & 70.0 & 1.5 & 39.8 & 34.0 \\
\hline $3.2 \mathrm{ppm}$ & 70.0 & 71.5 & 1.5 & 42.0 & 38.2 \\
\hline
\end{tabular}

Table 8. Alteration in average Tm-value ( - or + ) after treatment with Lannat

\begin{tabular}{cccc} 
U.V. Wave & Control & Lannat & or + \\
260 & 73.5 & 69.3 & -4.2 \\
280 & 75.5 & 71 & -4.5 \\
\hline
\end{tabular}

\section{REFERENCES}

Adler, I.D. 1984. Cytogenetic tests in mammals. In: Mutagenicity testing, a practical approach. Venitt. S. \& Parry, J.M., Eds., IRL Press, Oxford.

Allen, J.W., C.F. Shuler, R. Mendes and S.A. lett. 1977. A simplified technique for in vivo analysis of sister chromatid exchanges using 5-bromodeoxyuridine tablets. Cytogenet. Cell Genet. 18: 231-237

Al-sabti K. 1991. Hand book of genotoxic effects and fish chromosome,Institute Jozef Stefan, Ljubljana.

Bruges, W.A., J.H. Mc Cormick, T.W. Neiheisell, R.L. Spear, C.E. Stephan and G.N Stokes. 1977. Effects of pollution on fresh water fish. J.Water Poll. Contr. Fed.49:14251493.

Brusick, D. 1984. Principles of Genetic Toxicology. 2nd ed. New York, London: Plenum Press 1-43, 155.

Castell, J.D. and k. Tiewes. 1980. Report of the EIFAC, IUNS and ICES working group on the standardization of methodology in fish research, Hamburg, FRG. 21- 23 March. 1979. IFAC tech. Pap. (3) 24.

Coelho S., R. Oliveira, S. Pereira, C. Musso, I. Domingues, R.C. Bhujel, A.M.V.M. Soares, A.J.A. Nogueira. 2011. Assessing lethal and sub-lethal effects of trichlorfon on different trophic levels. Aquat. Toxicol. 103 pp. 191-198

Fellenberg, G. 1974. Chromosomal RoB proteins. Ulmer, Stuttgart.

lemming, C.A. and J.T. Trevor. 1980. Copper toxicity and chemistry in the environmental review Water, Air and Soil Pollution. 44: 143-158.
Jordaan M.S., S.A. Reinecke, A.J. Reineck. 2013. Biomarker responses and morphological effects in juvenile tilapia Oreochromis mossambicus following sequential exposure to the organophosphate azinphos-methyl Aquat. Toxicol., 144-145 (2013), pp. 133-140,

Nakanishi, Y. and El. Schneider. 1979. In vivo sister chromatid exchange: A sensitive measure of DNA damage. Mutat. Res. 60:329-337.

NRC. 1993. Nutrient requirements of fish. National Academy Press. Washington DC.

Ricker,W.E. 1975. Computatation and interpretation of biological statistics of fish population. Fish Research, Board Canada, Bull. 191.

Seehy, M.A., H.E. El-Wikil and N.U. Abass. 2009. The effect of water pollution on chromosomal behavior in Nile Tilapia, hournal of advances in agricultural researches, vo, 14(3): 689-703.

Spang, H.A., and R.S. Platt. 1972. The effect of plant growth substances on the hyperchromicity of DNA. Phyiol plant. 27: 321326 .

Tierney K., M. Casselman, S. Takeda, T. Farrell, C. Kennedy. 2007. Tierney, The relationship between cholinesterase inhibition and two types of swimming performance in chlorpyrifos-exposed coho salmon (Oncorhynchus kisutch) Environ. Toxicol. Chem., 26 (2007), pp. 9981004, 10.1897/06-459r.1

Var? F. Amat, J.C. Navarro. 2008. Acute toxicity of dichlorvos to Aphanius iberus (Cuvier \& Valenciennes, 1846) and its anti-cholinesterase effects on this species Aquat. Toxicol. 88, pp. 53-61, 10.1016/j.aquatox..03.004 


\section{الملخص العربي}

\section{تاثير مبيد اللانيت على معدل الاداء و التشؤهات الكروموسومية فى أسماك البلطى النيلى}

اسماء احمد السيد خالد

الثقيقة فى الكلى والخياشيم وقياس كمية الحامض النووى عن طريق تحليل الصور باستخدام الكمبيوثز بكلية الزراعة القاهرة-الجيزة وقياس بعض الخو اص الفيزيائية للكروماتين المعزول من الكبد. ويمكن تلخيص النتائج المتحصل عليها بان عدد الكروموسومات فى البلطى النيلى هى ع ؟ ؟ كروموسوم. يوجد منهم 1 كروموسومات ذات سنترومير قريب من الوسط(تحت وسطى)و رب كروموسوم ذات سنترومير قريب دن الطرف(تحت طرفى) وكان معدل الانقسام الميتوزى فى الخياشيم أقل منه فى الكلى وذلك فى الكنتزول حيث يؤدى المبيد الى انخفاض فى الانقسام الميتوزى بصفة عامة. وجد ان المبيد له القدرة على احداث ضرر و اضتح فى كمية ال DNA تتمثل فى كسور، نقص، التحام روبرتسونى ولزوجة ووجد أن بعض نواتجة الايضية لها القدرة على التفاعل مع ال DNA. كما وجد ان اللانيت لله القدرة على زيادة معدل احداث تبادل الكروموسومات DNA الثقيقة بصورة كبيرة جدا عن طريق تحديد كمية حيث تؤكد النتائج ان اللانيت او احد نواتجة الآيضية يؤثر تأثير| مباشرا على DNA . و ايضا وجد انة عن طريق تحليل الخواص الفيزيائية للكرماتين المعزول من كبد البلطى النيلى ان المبيد يؤدى الى تقليل درجة الانصهار

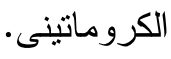

أجريت هذة الدر اسة بكلية الزر اعة- سابا باشا - جامعة

الاسكندرية - قسم الانتاج الحيو انى و السمكى بغرض در اسة تاثير المبيد الحشري اللانيت على أداء النمو و النشؤهات الكروموسومية فى أسماك البلطى النيلى. ثم الحصول على الأسماك من المزرعة السمكية بادكو كمصدر لسمك غير ملوث ونقلت الى معمل الأسماك ووضعت فى احواض ه زجاجية ونركت لمدة اسبو عين للناقلم ثم استخدام ثركيزات


واستخدمت مجموعة من الاسماك دون معاملة كمجموعة ضابطة. وقد تم تعريض السمك لهذه المعاملات لمدة 7 أسابيع وبعد ذلك تم الحصول على الخياشيم، الكبد و الكلى. أظهرت النتائج الخاصة باداء النمو أن هنالك فرقاً معنوياً بين جميع المعاملات مقارنة بالمجموعة الضابطة(الكنترول) حيث أدى التعرض لهذه التركيزات إلى خفض معنوى لمعدلات نمو الأسماك وكذلك معدل الإعاشة وذلك على مستوى حسابات كل من الوزن النهائى، الزيادة فى الوزن، متوسط الزيادة اليومية، معدل النمو النوعى. وثم قياس معدل الانقسام الميتوزى فى كل من الخياشيم و الكلى وفحصت الكروموسومات لمعرفة عددها وشكلها ومعرفة الهيئة الكروموسومية ودر اسة السلوك الكروموسومى الثاذ بانو اعه المختلفة وقياس معدل حدوث تبادل الكرومتيدات 